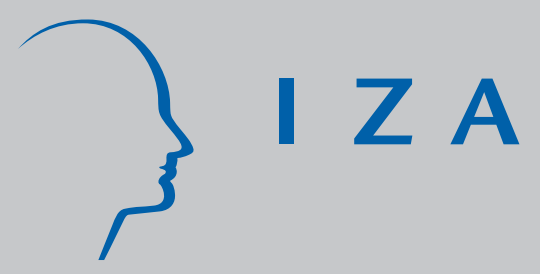

IZA DP No. 3124

Immigrants, English Ability and the Digital Divide

Hiroshi Ono

Madeline Zavodny

October 2007 


\title{
Immigrants, English Ability and the Digital Divide
}

\author{
Hiroshi Ono \\ Texas A\&M University \\ Madeline Zavodny \\ Agnes Scott College \\ and IZA
}

Discussion Paper No. 3124

October 2007

\author{
IZA \\ P.O. Box 7240 \\ 53072 Bonn \\ Germany \\ Phone: +49-228-3894-0 \\ Fax: +49-228-3894-180 \\ E-mail: iza@iza.org
}

\begin{abstract}
Any opinions expressed here are those of the author(s) and not those of the institute. Research disseminated by IZA may include views on policy, but the institute itself takes no institutional policy positions.

The Institute for the Study of Labor (IZA) in Bonn is a local and virtual international research center and a place of communication between science, politics and business. IZA is an independent nonprofit company supported by Deutsche Post World Net. The center is associated with the University of Bonn and offers a stimulating research environment through its research networks, research support, and visitors and doctoral programs. IZA engages in (i) original and internationally competitive research in all fields of labor economics, (ii) development of policy concepts, and (iii) dissemination of research results and concepts to the interested public.
\end{abstract}

IZA Discussion Papers often represent preliminary work and are circulated to encourage discussion. Citation of such a paper should account for its provisional character. A revised version may be available directly from the author. 
IZA Discussion Paper No. 3124

October 2007

\section{ABSTRACT}

\section{Immigrants, English Ability and the Digital Divide}

This study examines the extent and causes of inequalities in information technology (IT) ownership and use between natives and immigrants in the U.S., focusing on the role of English ability. The results indicate that, during the period 1997-2003, immigrants were significantly less likely to have access to or use a computer and the Internet. Moreover, the gap in IT usage widened during that period. Immigrants (and natives) who live in Spanishspeaking households are less likely than individuals living in English-speaking households to have access to or use IT. Estimates using a measure of predicted English ability show that English ability is positively associated with IT access and use. The results suggest that much of the immigrant-native gap in IT usage is attributable to differences in English ability.

JEL Classification: J61, F22, O33

Keywords: information technology, immigrants, English ability

Corresponding author:

Madeline Zavodny

Department of Economics

Agnes Scott College

141 E. College Ave.

Decatur, GA 30030

USA

E-mail: mzavodny@agnesscott.edu 


\section{Immigrants, English Ability and the Digital Divide}

Access to a computer and the Internet and the ability to use those resources are widespread in the U.S. and perhaps even taken for granted by many individuals, yet sizable disparities in information technology (IT) access and use persist along racial and ethnic lines. The gap between Hispanics and white non-Hispanics in IT usage actually increased during the late 1990s and early 2000s despite increases in computer and Internet usage rates among Hispanics, according to a report by the U.S. Department of Commerce (2002). The report notes that the gap is due in part to differences in English ability; Internet use among Hispanics is considerably lower if Spanish is the only language spoken in the household, as is the case among many families that emigrated from Latin America.

This study examines the extent and causes of digital inequality, or differences in IT access and use, between natives and immigrants in the U.S., with particular focus on the role of English-language skills. ${ }^{1}$ Assessing digital inequality is important because of its potential contribution to economic and social inequality. IT skills are widely acknowledged to be crucial to success in the workplace and at school, and they play a vital role in civic and political engagement (e.g., Norris 2001; DiMaggio et al. 2004). While individuals who lack IT access and skills may have more limited life chances, the reverse is also true, as noted by Warschauer (2003); groups that are already marginalized may have fewer opportunities to use IT and acquire technological skills than do privileged groups. Indeed, computerization appears to be a key

\footnotetext{
${ }^{1}$ We use the terms "foreign-born" and "immigrant" interchangeably throughout to encompass all individuals who are foreign-born, regardless of visa and citizenship status. The Current Population Survey and decennial Census data used here do not ask about visa status. All individuals born abroad and not a U.S. citizen at birth are considered immigrants here. Individuals born in Puerto Rico or in the U.S. territories or to a U.S. citizen living abroad are not considered foreign-born because they are U.S. citizens at birth.
} 
factor in the polarization of the U.S. labor market in recent decades (Autor, Katz, and Kearney 2006).

The literature on digital inequality in the U.S. has advanced from examining the extent and causes of differences in IT access and use to focusing on differences in intensity and types of use. While early research studied, for example, digital divides by sex, race, and income in computer ownership and Internet access (e.g., Hoffman and Novak 1998; Bikson and Panis 1999; Kominski and Newburger 1999; Ono and Zavodny 2003), subsequent studies emphasize differences in frequency of use, types of applications used, and access to emerging technologies such as broadband (e.g., Robinson, DiMaggio and Hargittai 2003; U.S. Department of Commerce 2004). The shift in focus rests on the belief that differences in access have become less problematic as computer ownership has become widespread and as public spaces such as libraries and community centers have made computers and Internet access widely available (e.g., Noll et al. 2001). In addition, some scholars argue that IT diffusion will eventually reach a saturation point. They believe that, as occurred for other technologies such as the television and the telephone, high volume will drive down IT prices, reduce the skill levels required for use, and cause gaps in access and use between the privileged and the unprivileged to diminish (Compaine 2001; Leigh and Atkinson 2001). Others argue that computers and the Internet will never reach all households, in part because Internet access requires monthly fees (DiMaggio et al. 2004; Warschauer 2003).

We argue that while digital inequality may have indeed diminished along some dimensions, one cannot generalize this conclusion to all groups. Rates of IT access and use among immigrants have been largely overlooked by previous research, but as we show, there are substantial gaps in IT usage between immigrants and natives. Understanding the extent and 
causes of immigrant-native differences in IT usage is necessary before shifting focus from the crucial question of inequality in access and use to the issue of differentiated patterns of use.

Assessing digital inequality between immigrants and natives is important not only because of the significant influence of IT access and skills on employment, educational opportunities, and civic engagement but also because many immigrants—-particularly those from Latin America—are disadvantaged relative to natives in the U.S. Immigrants are disproportionately unskilled, have limited English skills, and are in lower socioeconomic status groups (Quian and Lichter 2007). Although the average education level of immigrants has risen slightly since 1970, the gap between immigrants' and natives' average educational attainment has increased (Betts and Lofstrom 2000). Data from the 2000 Census indicate that over 56\% of adult immigrants from Latin America have less than 12 years of education, compared with less than $17 \%$ of natives. Similarly, the gap between immigrants' and natives' average earnings has widened since about 1970 (Butcher and DiNardo 2002; Card 2005) and is particularly large for immigrants from Latin America (e.g., Carliner 1996). ${ }^{2}$ Immigrant residential segregation has also been increasing in recent decades (Cutler, Glaeser, and Vigdor 2005). This concentration in segregated communities limits immigrants' interaction with natives and magnifies their social distance from mainstream society (Quian and Lichter 2007). Given all of these disadvantages, lack of IT access and skills may be one of many barriers to socioeconomic advancement and assimilation for immigrants.

This study uses data from several supplements to the Current Population Survey during the period 1997 to 2003 to estimate the extent and determinants of native-immigrant differentials in computer ownership and IT use. We focus in particular on the role of English ability in

\footnotetext{
${ }^{2}$ However, Duleep and Regets (1997) indicate that immigrants with lower earnings at entry experience faster wage growth, which suggests that the decline in immigrants' average earnings at entry may be offset by an increase in average earnings growth.
} 
immigrants' lower rates of IT usage. The results indicate that there is a large gap in computer and Internet access and use between immigrants and natives, and these differences appear to have widened over the period we examine. Rates of IT use are particularly low among individuals who are likely to have limited English proficiency.

\section{Background}

There are several reasons why immigrants may be less likely to have access to and to use IT than natives. First, as noted by many previous studies, digital divides tend to mirror preexisting patterns of inequality (e.g., DiMaggio et al. 2001; Korupp and Szydlik 2005; Ono and Zavodny 2007; Warschauer 2003). Immigrant households tend to be disadvantaged along many dimensions usually associated with lower rates of IT usage, such as race, income, and education. In particular, immigrant households tend to be poorer and less educated than households headed by a U.S. native (U.S. Census Bureau 2004a,b). Since there are pronounced disparities in IT ownership and use by income and education (e.g., van Dijk and Hacker 2003; Warschauer 2003), this alone suggests that immigrants have lower rates of IT ownership and use. In addition, immigrant households have lower literacy rates and less wealth, on average, creating additional barriers to IT usage.

Second, limited English proficiency may be an important obstacle to IT use, particularly of the Internet, for the many immigrants who lack English fluency. Over one-half of immigrants in the 2000 Census reported they do not speak English very well. The vast majority of Internet sites are in English, with 68\% of web pages in English and only 3\% in Spanish in 2000 (Spooner and Rainie 2001). According to the Organisation for Economic Co-operation and Development (OECD 2001), 94\% of links to web pages on secure servers were in English as of July 2000, 
suggesting that English language skills may be a barrier to online transactions such as banking. bill-paying, and purchases.

Finally, many immigrant households may lack social networks that would enhance their opportunities to acquire IT access and skills. The literature on the digital divide emphasizes the importance of being able to draw on social support for IT help (DiMaggio et al 2004; Hargittai 2003). Individuals with many friends and relatives who own computers and use email are more likely to do so as well because they have both a lower cost of doing so-because their network helps them learn how to use IT—and a greater return to use because they have a large social network online (Goolsbee and Klenow 2002). For example, some low-income families who were given a computer as part of a training and distribution program later passed it on to someone else in their social network (Mehra, Merkel, and Bishop 2004). Given the low average rates of IT use among immigrants that we show here and the general tendency of homophilious interactions, many immigrants' social networks probably have relatively low rates of IT use. These network effects are an additional reason why digital divides reflect and even exacerbate social inequality.

Virtually no research has been conducted on differences in IT access and use between immigrants and natives in the U.S. and the causes of any such differences. ${ }^{3}$ A few studies have examined whether Hispanics—which includes both natives and immigrants—differ from nonHispanics in their use of IT. Fairlie (2003, 2004) reports that all major groups of Latinos have lower rates of computer and Internet use than non-Hispanic whites, with the lowest rates occurring among Mexican-Americans. He concludes that differences in education and income can only partially account for the observed gaps in computer ownership and Internet use. Fairlie

\footnotetext{
${ }^{3}$ Chiswick and Miller (2007) examine immigrant-native differentials in computer use in Australia. Korupp and Szydlik (2005) report that Turkish citizens living in Germany are significantly less likely to use a computer or the Internet than German citizens even when controlling for human capital, family context, and social contexts.
} 
(2004) also notes that computer ownership rates and Internet use are much lower among Latinos who live in non-English-speaking households, suggesting that English language skills play a large role in IT use.

In this study, we investigate in greater depth the effect of English ability on IT access and use. The scant available literature in this field is mostly limited to cross-country national-level comparisons of IT diffusion that include a fairly crude measure of English ability among the population as a whole. ${ }^{4}$ Empirical studies of non-U.S. countries suggest that English is a barrier to computer use and Internet access. ${ }^{5}$ In the U.S., immigrants' economic advancement and earnings are clearly linked to English ability (e.g., Bleakley and Chin 2004), but the role of English ability in digital inequality has not been thoroughly investigated.

\section{Data and Methods}

We use data from the Current Population Survey (CPS) and the 2000 Census. The CPS is a monthly survey of labor force behavior conducted in more than 50,000 U.S. households that is representative of the U.S. population. In October 1997, December 1998, August 2000, September 2001, and October 2003, the CPS included a supplemental questionnaire on computer ownership and usage. This analysis uses the CPS because it is the largest U.S. survey that includes questions on IT usage and therefore yields the most precise estimates of the

\footnotetext{
${ }^{4}$ Hargittai (1999) examines how English ability affects Internet connectivity among 18 OECD countries using a three category measure of English ability and does not find any significant effect of English language on Internet connectivity. Caselli and Coleman (2001) examine the determinants of computer-technology adoption using a large sample of countries between 1970 and 1990 and similarly conclude that English language skills (measured as the proportion of the population that speaks English as a first language) do not affect diffusion. ${ }^{5}$ Chiswick and Miller (2007) find that computer usage is positively related to English ability among both immigrants and natives in Australia. Ono and Zavodny (20054) explain that the low level of English literacy in Japan may have contributed to the lower rates of computer and Internet usage there relative to the U.S. In a case study of Singapore, ITU (2001) examines patterns of Internet use across the four official language groups - Chinese, Malay, Tamil, and English - and also across groups with different English speaking abilities. It finds that those who do not speak English well have much lower rates of Internet usage. Zoghi and Pabilonia (2007) find in Canadian data that workers who speak a different language at home than at work are less likely to use a computer at work than workers who speak the same language (presumably English for most of the sample) at home and at work.
} 
determinants of IT usage. The questions about computer and Internet use in the CPS changed across some of the surveys, so not all years are included in all regressions. Our main sample from the CPS includes all individuals aged 18 and older with complete responses to the questions used here, giving a total sample size of 402,778 observations. ${ }^{6}$ All results using the CPS data are weighted using the CPS population weights.

The analysis in this study examines several measures of IT access and use, including whether an individual lives in a household that owns a personal computer; whether a person uses a computer or the Internet at home, given computer ownership; whether an individual uses a computer at work, given that s/he works; and whether an individual uses the Internet at any location. We include the last variable in order to examine the possibility that immigrants rely more than natives on Internet access via computers in public places, such as libraries and community centers. ${ }^{7}$ The computer use at home and computer use at work measures are only available in the 1997, 2001, and 2003 surveys. Table 1 reports the sample means for these IT variables by immigrant status. Immigrants consistently have lower rates of IT usage. For example, about $47 \%$ of immigrants live in a household that owns a computer compared with $57 \%$ of natives (the narrowest gap), and about $36 \%$ of immigrants who work use a computer at work compared with about $57 \%$ of natives who work (the widest gap).

We estimate multinomial logistic regressions for each of these measures of IT access and use. The dependent variable in each regression is a measure of IT usage that equals 1 if an individual uses that type of IT and 0 otherwise. All regressions include an immigrant indicator variable equal to 1 for immigrants and 0 for natives that is the focus of the analysis. For ease of

\footnotetext{
${ }^{6}$ Family income was not reported by about $14 \%$ of individuals aged 18 and older in the CPS, and we dropped all of these individuals.

${ }^{7}$ The specific locations asked about in the CPS increased over time. The survey year fixed effects should control for average differences in Internet usage at any location across survey years due to more locations being included in the survey over time.
} 
interpretation, we report odds ratios. The estimated odd ratios for the immigrant variable give the relative odds of IT usage among immigrants compared with natives, with ratios greater (less) than 1 indicating that immigrants are more (less) likely than natives to use IT.

The regressions also contain a large set of covariates that control for demographic and socioeconomic characteristics. We include variables measuring individuals' age (a quartic, or age, age ${ }^{2}$ age $^{3}$, and age ${ }^{4}$ ), sex, race, ethnicity, education (3 of 4 categories), marital status, family income (13 of 14 categories), and state of residence. Sample means for most of these variables are shown by immigrant status in Table 1; the sample means for the income variables are shown in Appendix Table 1. In the regressions, the family income indicator variables are interacted with survey year indicator variables to control for inflation and business cycle effects. ${ }^{8}$ The regressions also include survey year fixed effects.

Most regressions contain a linear variable measuring year of U.S. residence among immigrants. We created this variable using the midpoints of the year ranges given in the CPS. ${ }^{9}$ This variable could be interpreted as measuring whether immigrants “catch up” with natives' rates of IT usage as immigrants' duration of U.S. residence increases. However, we caution that the years of residence variable will not only capture such assimilation effects but also any cohort effects (see Borjas 1985 for a discussion). If immigrant "quality" is declining over time and this causes IT rates to be lower among more recent immigrants, but immigrants do assimilate over time toward natives' higher rates of IT usage, then the estimated years of U.S. residence coefficients will overstate assimilation effects. We do not include controls for cohort because our data cover only a 7-year period.

\footnotetext{
${ }^{8}$ The family income categories in the 2003 survey include 3 high income categories that are collapsed into \$75,000 and higher here for consistency with the other survey years.

${ }^{9}$ However, the CPS data on year of arrival do not necessarily correspond to the year an individual first or most recently entered the U.S. and therefore contain measurement error. See Redstone and Massey (2004) for a discussion. Year of U.S. residence is defined as 0 for all natives and is identified only from immigrant observations.
} 
Although the CPS has a large number of questions about socioeconomic characteristics and IT usage, the survey does not ask individuals about their proficiency in English. The survey can be conducted in either English or Spanish, and the data include a variable indicating whether everyone in the household aged 15 or older speaks only Spanish. Because the CPS excludes other non-English-speaking households, we probably underestimate the true extent of immigrantnative differences in IT usage. We use the Spanish-speaking-household variable in our analysis, but we also want to measure the effect of English ability on IT usage among non-Spanishspeaking immigrants and to examine the effect of varying degrees of English proficiency. We therefore turned to the 2000 Census, which includes the same socioeconomic variables as the CPS but also has self-reported ability to speak English among individuals who report speaking a language other than English at home. The Census does not ask any questions about IT usage. The categories for this English ability variable are not at all, not well, well, and very well (in addition to speaking only English at home). We coded this variable as ranging from 0 to 4, with higher values indicating higher ability (so 4 indicates speaks only English at home).

We used the Census data to impute English ability to individuals in the CPS based on their socioeconomic characteristics and on self-reported English ability in the Census among individuals with similar socioeconomic characteristics. First, we kept all individuals in the 5\% Public Use Microdata Sample (PUMS) from the 2000 Census aged 18 or older living in a household in which someone aged 15 or older spoke any English or Spanish. ${ }^{10}$ We then drew a random 10\% sample of individuals who reported speaking only English at home and combined this with the full sample of individuals who reported speaking a language other than English at

\footnotetext{
${ }^{10}$ These individuals would not be included in the CPS since that survey requires that someone age 15 or older complete the survey in English or Spanish. The Census is conducted in more languages than the CPS; the questionnaire was available in 5 other languages and language assistance guides were available in 49 other languages. We also did not include any individuals in the Census living in group quarters for comparability to the CPS data.
} 
home. Descriptive statistics for the Census sample are shown in Appendix Table 2. The Census sample appears to be quite similar to the CPS sample.

We estimated an ordered logit regression of English ability with the Census data. The dependent variable is the self-reported measure of English ability. The covariates include the immigrant indicator variable, year of U.S. residence among immigrants, and all of the other variables measuring socioeconomic characteristics discussed above for the CPS regressions.

The covariates in the English ability regression also include an indicator variable measuring U.S. citizenship status, a linear variable measuring the fraction of the population in an individual's country of birth that speaks English, and an interaction of the fraction speaking English variable and years of U.S. residence variable. These three variables identify the firststage regression because they are not included in the computer use (second-stage) regressions. We argue that these variables are good predictors of English ability but should not be associated with IT usage except via English ability. Immigrants (except for the elderly) must pass a test administered in English to become naturalized U.S. citizens, suggesting that naturalized citizens will speak English more fluently than other immigrants. About $43 \%$ of immigrants in the Census sample reported being a naturalized U.S. citizen, and about 39\% of immigrants in the CPS sample. The fraction of the population that speaks English in an individual's country of birth also should be positively associated with an individual's English ability. These data are from from Hall and Jones (1999). The average English-speaking fraction is about 0.88 among natives in both samples (reflecting both the fact that not all people in the U.S. speak English and that some U.S. natives are born abroad to the parents of U.S. citizens) and about 0.08 among immigrants in both samples. The interaction term between years of U.S. residence among immigrants and the fraction of the population that speaks English in the birth country captures 
differences in language assimilation among immigrants from countries in which many or few people speak English.

The results of the ordered logit regression were largely as expected. As shown in Appendix Table 3, ability to speak English is lower among immigrants than natives, on average, but appears to increase with years of U.S. residence (although this coefficient may be upwards biased because of cohort effects). Immigrants who are naturalized U.S. citizens have greater English fluency, as do people born in countries where a higher fraction of the population speaks English. The three variables (U.S. citizen, fraction speak English, and the interaction term) are jointly statistically significantly different from zero (chi-squared statistic of 29,109, with a pvalue of 0.00 ).

We then used the estimated coefficients from the ordered logit regression to predict English ability for individuals in the CPS who report the same country or region of birth. We used the cutoffs and estimated coefficients to predict into which of the 5 English categories each person in the CPS sample is most likely to fall. The predicted categorical variable ranges from 0 to 4. We then created indicator variables for 4 of the 5 categories (with speaking only English at home as the omitted category). These indicator variables are included as measures of (predicted) English ability in the IT regressions in order to examine the effect of English proficiency on IT usage.

The predictions appear to be quite good. In our Census sample, we correctly predicted the category of English ability for $85 \%$ of our sample. The association between the reported and predicted measure of English ability is high, with a gamma equal to 0.96 and Kendall's tau-b of 0.76. In our CPS sample, the mean of the predicted English ability variable is 3.75. Among immigrants, it is 2.20 , which is between "not very well" and "well," with about $3 \%$ predicted to 
not speak any English and 38\% predicted to speak English not well (Table 1). Almost 98\% of natives were predicted to speak only English, and most of the others were predicted to speak English very well. English ability is highly correlated with education among immigrants; in the Census data, over $70 \%$ of college graduates speak English as least very well while over 54\% of non-high school graduates speak English not well or not at all.

\section{Results}

The results indicate that immigrants are substantially less likely than natives to use IT for every measure of IT that we examine. All regressions reported in Tables 2 to 4 control for the other socioeconomic characteristics listed above, state of residence, and survey year, but we do not show those coefficients in the tables.

The top panel of Table 2 reports the odds ratio for immigrants relative to natives from separate logistic regressions for each measure of IT access and use. Immigrants are less likely than natives to have access to or use computers and the Internet across all of the outcomes we examine here. The immigrant-native odds ratio is about 0.87 for computer ownership; 0.56 for using a computer at home and 0.70 for using the Internet at home, conditional on living in a household that owns a computer; 0.55 for using a computer at work, conditional on working; and 0.62 for using the Internet at any location, controlling for differences in age, sex, education, race, ethnicity, and family income. These odds ratios—all of which are statistically significant_-are smaller than the raw ratios in usage implied by the sample means in Table 1, indicating that 
differences in education, family income, and other factors contribute to the immigrant-native differentials in IT usage but do not fully account for them. ${ }^{11}$

Other socioeconomic characteristics are associated with IT use in patterns well documented elsewhere (e.g., DiMaggio et al. 2004). In results not shown here, racial and ethnic minorities are less likely to own or use computers and the Internet, while education and family income are positively associated with IT usage. ${ }^{12}$ Women are more likely than men to use computers at home and at work and the Internet at any location but are less likely to use the Internet at home.

Immigrants appear to have fallen further behind natives' rates of IT usage during the period 1997-2003. During this period, rates of computer ownership and use and Internet use increased for both immigrants and natives (Figure 1). However, Figure 1 suggests that the gap between immigrants and natives generally widened. To further examine changes over time, we estimated regressions with interactions between the immigrant indicator variable and survey year indicator variables. The results, shown in the bottom panel of Table 2, are relative to natives in that survey year, controlling for differences in other socioeconomic characteristics. The relative odds for immigrants' computer ownership, home computer use, home Internet use, and Internet use anywhere are all lower in 2003 than in 1997 and typically decreased monotonically over time. The one exception is that the immigrant-native difference in computer use at work did not change significantly during this period.

The logistic regressions shown in the bottom panel of Table 2 also include a variable measuring years of U.S. residence among immigrants. The odd ratios for this variable are very

\footnotetext{
${ }^{11}$ The large sample size (over 400,000 observations) should be kept in mind when interpreting the very small standard errors and high significance levels for most coefficients. We focus more on the magnitude of the coefficients than on whether they are significantly different from zero.

${ }^{12}$ Full regression results are available from the authors on request.
} 
close to 1 but typically slightly above 1, suggesting that immigrants' IT usage increases over time. Although this finding seems plausible, we again caution that these results could be upwards biased if earlier cohorts of immigrants are more skilled and hence more likely to use IT, controlling for age, education, and other observable characteristics.

Differences in English ability may underlie the immigrant-native gap in IT access and use documented in Tables 1 and 2. To further investigate this possibility, we first included in the regressions a variable indicating whether an individual lives in a household in which all adults speak only Spanish — the only measure of language in the CPS—interacted with indicator variables for immigrants and natives. The immigrant coefficient gives the relative odds of IT usage for immigrants compared with natives, controlling for other factors. The interaction between the immigrant variable and the Spanish-speaking household variable gives the relative odds for immigrants in households that only speak Spanish compared with immigrants in households in which an adult speaks English well enough to answer the survey in English. The interaction between the native variable and the Spanish-speaking household variable gives the relative odds for natives in households that only speak Spanish compared with other natives. About $17 \%$ of the sample of immigrants lives in Spanish-only households, and less than 1\% of the sample of natives (most of whom were born in Puerto Rico and hence are U.S. citizens at birth).

The results indicate that individuals living in Spanish-speaking households are generally much less likely to live in a household that owns a computer and to use IT. For example, the odds ratio for living in a household that owns a computer is 0.42 for immigrants living in a Spanish-speaking household compared with other immigrants, and 0.85 for natives in a Spanishspeaking household compared with other natives. The odds ratios are lower for immigrants than 
for natives, but the results suggest that poor English skills are a barrier to IT usage even for some natives.

We next included the predicted measure of English ability based on Census data, created as discussed above, in the regressions. All of the odds ratios, which are reported in Table 4, are relative to individuals who are predicted to speak only English at home (the omitted group). The results indicate that English ability is strongly related to IT usage, controlling for other characteristics, including household income. Almost all of the coefficients are less than 1, and most are monotonically decreasing as predicted English ability worsens. For example, the relative odds that someone who is predicted to not speak any English lives in a household with a computer are 0.06 compared with someone who is predicted to only speak English; 0.35 for using a computer at home and 0.38 for using the Internet at home, given computer ownership; 0.56 for using a computer at work; and 0.32 for using the Internet at any location. Compared with the earlier specifications, most of the estimated odds ratios for the immigrant indicator variable become considerably larger in magnitude (closer to 1) when we control for predicted English ability. This suggests that much—although not all—of the immigrant-native differential in IT use is due to differences in English ability.

Interestingly, the immigrant-native gaps tend to be smaller, with odds ratio closer to 1 , for computer ownership than for the other measures of IT usage we examine. This occurs in both the sample means and the regression results. In addition, except for immigrants who are predicted to not speak any English, English ability does not appear to be as tightly linked to computer ownership as to other measures of IT usage. Like other studies (e.g., Stanley 2003), our findings thus show that access does not necessarily translate into use; conditional on access at home, immigrants still are less likely than natives to use a computer or the Internet at home 
and elsewhere. This difference between access and use may be particularly important in "mixed nativity" households that include both immigrants and natives; immigrants may be less likely than natives to use a computer within such households. For example, immigrant parents might purchase a computer for use by their native-born children; in our sample, such parents would be observed living in a household that owns a computer even if they themselves never use it.

Our finding that immigrants are less likely than natives to use the Internet at any location is of particular interest because it implies that attempts to create universal access at libraries, community centers, and other locations have not succeeded in erasing all gaps in IT use. However, in results not shown in the tables, we do not find a significant difference between immigrants and natives in Internet use at public libraries. In other words, immigrants and natives are equally likely to use the Internet at a public library. This similarity is particularly striking given that immigrants are less likely than native to use the Internet at home, conditional on owning a computer. This suggests that the cost of Internet access may be a barrier to usage even among immigrants who own a computer. One of the few qualitative questions the CPS asks about IT usage is why individuals don't have the Internet at home in the 2003 survey. Among individuals who do not have Internet access at home, the proportion attributing it to "costs are too high” was 10 percentage points greater among immigrants than natives (33\% versus 23\%). Natives were 13 percentage points more likely than immigrants to respond “don’t need it, not interested," in contrast.

\section{Summary and Discussion}

This study examined the extent and causes of differences in IT access and use between natives and immigrants in the U.S. Our findings consistently show that immigrants are less 
likely to have access to and use a computer and the Internet. Moreover, this immigrant-native gap (with the exception of computer use at work) widened during the years 1997 to 2003, a time period when most other digital divides narrowed as computer ownership and Internet use became widespread in most of the U.S. English ability appears to play an important role in this gap. The immigrant-native gap is larger among immigrants who live in households that only speak Spanish, and our results using a measure of predicted English ability show that better ability to speak English is strongly associated with higher access and usage rates.

Our consistent finding that immigrants are less likely to use IT than natives is in striking contrast to results for Australia reported by Chiswick and Miller (2005). They find that immigrants there are more likely than comparable natives to use computers. We find the opposite result for the U.S. These disparate findings are intriguing given the difference in admissions criteria for the two countries, with Australia placing relatively more weight on skills and the U.S. on family reunification (Antecol, Cobb-Clark, and Trejo 2003). Like this study, Chiswick and Miller indicate that English skills are important to computer use. In addition, a study of nine former Soviet-block countries also indicates that workers who can speak English are the most likely to work with computers (and earn a sizable earnings premium for doing so) (Kuku, Orazem, and Singh 2007).

Access to the Internet and the ability to use a computer are becoming increasingly critical for immigrants as immigration-related government agencies shift to providing services via the Internet. For example, U.S. Citizenship and Immigration Services encourages individuals to use an Internet-based system, Infopass, to schedule appointments with immigration officers instead of waiting in line at offices. ${ }^{13}$ Immigration forms and case status are now also available over the

\footnotetext{
${ }^{13}$ Infopass is available in 12 different languages (English plus 11 foreign languages). See: http://infopass.uscis.gov/
} 
Internet. Our research suggests that a sizeable proportion of the immigrant population is unable to use these online services.

An important issue we are not able to explicitly address using the Current Population Survey is whether immigrants have different attitudes than natives toward owning and using computers. Our results indicate that predicted English ability is significantly associated with computer use, but we do not know whether immigrants themselves perceive their English skills as a limitation to IT usage. Research using data from surveys that ask more qualitative questions is an important area for further study on immigrant-native differentials in IT usage. We also do not examine whether the costs and benefits of using IT, beyond the role of English ability, differ among immigrants and natives. For example, immigrants may have lower returns than natives to using IT at work because of differences in occupation and industry.

A key agenda for future research is to move beyond measuring the extent and trends in immigrant-native differentials in IT access and use. Differences in multi-dimensional measures of use- such as uses of the computer and modes of Internet access-as well as differences in ability to use IT are important areas unaddressed as yet. The underlying causes of such differences, including the role of English ability, are also worthy of attention. Given the importance of IT in schools and workplaces as well as the growing numbers of immigrants and their children — who may grow up in households that speak a language other than English—in the United States, assessing and understanding digital inequality among immigrants is important for both academics and policy makers. 


\section{References}

Antecol, Heather, Deborah A. Cobb-Clark, and Stephen J. Trejo. 2003. "Immigration Policy and the Skills of Immigrants to Australia, Canada, and the United States.” Journal of Human Resources 38: 192-218.

Autor, David H., Lawrence F. Katz, and Melissa S. Kearney. 2006. "The Polarization of the U.S. Labor Market.” American Economic Review Papers \& Proceedings 96: 189-194..

Betts, Julian R. and Magnus Lofstrom. 2000. “The Educational Attainment of Immigrants: Trends and Implications.” Pp. 51-115 in Issues in the Economics of Immigration. Edited by George J. Borjas. Chicago: University of Chicago Press.

Bikson, Tora K. and Constantijn Panis. 1999. Citizens, Computers, and Connectivity. Santa Monica, CA: RAND.

Bleakley, Hoyt and Aimee Chin. 2004. "Language Skills and Earnings: Evidence from Childhood Immigrants.” Review of Economics and Statistics 86: 481-496.

Borjas, George J. 1985. “Assimilation, Changes in Cohort Quality, and the Earnings of Immigrants.” Journal of Labor Economics 3: 463-489.

Butcher, Kristin F. and John DiNardo. 2002. “The Immigrant and Native-Born Wage Distributions: Evidence from United States Censuses.” Industrial and Labor Relations Review 56: 97-121.

Card, David. 2005. “Is the New Immigration Really So Bad?” Economic Journal 115: 300-323.

Carliner, Geoffrey. 1996. “The Wages and Language Skills of U.S. Immigrants.” NBER Working Paper No. 5763.

Caselli, Francesco and W. John Coleman. 2001. "Cross-Country Technology Diffusion: The Case of Computers.” NBER Working Paper No. 8130.

Chiswick, Barry C. and Paul W. Miller. 2007. “Computer Skills, Destination Language Proficiency and the Earnings of Natives and Immigrants.” Review of Economics of the Household 5: 129-157.

Compaine, Benjamin M. 2001. "Declare the War Won.” Pp. 315-335 in The Digital Divide: Facing a Crisis or Creating a Myth? Edited by Benjamin M. Compaine. Cambridge: MIT Press.

Cutler, David M., Edward L. Glaeser, and Jacob L. Vigdor. 2005. "Is the Melting Pot Still Hot? Explaining the Resurgence of Immigrant Segregation.” NBER Working Paper No. 11295.

DiMaggio, Paul, Eszter Hargittai, W. Russell Neuman, and John P. Robinson. 2001. "Social Implications of the Internet.” Annual Review of Sociology 27: 301-336. 
DiMaggio, Paul, Eszter Hargittai, Coral Celeste, and Steven Shafer. 2004. "Digital Inequality: From Unequal Access to Differentiated Use.” Pp. 355-400 in Social Inequality. Edited by Kathryn M. Neckerman. New York: Russell Sage Foundation.

Duleep, Harriet Orcutt, and Mark C. Regets. 1997. "Measuring Immigrant Wage Growth using Matched CPS Files.” Demography 34: 239-249.

Fairlie, Robert W. 2003. "Is There a Digital Divide? Ethnic and Racial Differences in Access to Technology and Possible Explanations.” Mimeo, University of California, Santa Cruz Department of Economics, November.

. 2004. "Race and the Digital Divide.” Contributions to Economic Analysis \& Policy 3.

Goolsbee, Austan and Peter Klenow. 2002. "Evidence on Learning and Network Externalities in the Diffusion of Home Computers.” Journal of Law and Economics 45: 317-344.

Hall, Robert E., and Charles I. Jones. 1999. "Why Do Some Countries Produce So Much More Output per Worker than Others?” Quarterly Journal of Economics 114: 83-116.

Hargittai, Eszter. 1999. "Weaving the Western Web: Explaining Differences in Internet Connectivity among OECD Countries.” Telecommunications Policy 23: 701-718.

2003. “The Digital Divide and What To Do About It.” Pp. 821-839 in New Economy Handbook. Edited by Derek C. Jones. San Diego: Academic Press.

Hoffman, Donna and Thomas Novak. 1998. "Information Access: Bridging the Racial Divide on the Internet.” Science 280: 390-291.

International Telecommunciation Union (ITU) .2001. The e-City: Singapore Internet Case Study. Geneva: ITU.

Kominski, Robert and Eric Newburger. 1999. “Access Denied: Changes in Computer Ownership and Use: 1984-1997.” Mimeo, Population Division, U.S. Census Bureau.

Korupp, Sylvia E. and Marc Szydlik. 2005. "Causes and Trends of the Digital Divide.” European Sociological Review 21: 409-422.

Kuku, Yemisi, Peter F. Orazem, and Rajesh Singh. 2007. "Computer Adoption and Returns in Transition.” Economics of Transition 15: 33-56.

Leigh, Andrew and Robert Atkinson. 2001. “Clear Thinking on the Digital Divide.” Progressive Policy Institute. Available on-line at http://www.dlc.org/documents/digital_divide.pdf [accessed February 14, 2006]. 
Mehra, Bharat, Cecelia Merkel, and Ann Peterson Bishop. 2004. “The Internet for Empowerment of Minority and Marginalized Users.” New Media \& Society 6: 781-802.

Noll, Roger G., et al. 2001. “The Digital Divide: Definitions, Measurement, and Policy Issues.” In Bridging the Digital Divide, California Council on Science and Technology. http://www.ccst.us/ccst/pubs/cpa/bdd/BDDreport/BDD05.html

Norris, Pippa. 2001. Digital Divide: Civic Engagement, Information Poverty and the Internet in Democratic Societies. New York: Cambridge University Press.

Organisation for Economic Co-operation and Development (OECD). 2001. Understanding the Digital Divide. Paris: OCED.

Ono, Hiroshi and Madeline Zavodny. 2003. “Gender and the Internet.” Social Science Quarterly 84: 111-121.

. 2005. "Gender Differences in Information Technology Usage: A U.S.-Japan

Comparison.” Sociological Perspectives 48: 105-133. . 2007. "Digital Inequality: A Five Country Comparison Using Microdata.” Social Science Research 36: 1135-1155.

Quian, Zhenchao and Daniel T. Lichter. 2007. "Racial Boundaries and Marital Assimilation: Interpreting Trends in Racial and Ethnic Intermarriage.” American Sociological Review 72: 6894.

Redstone, Ilana and Douglas S. Massey. 2004. "Coming to Stay: An Analysis of the U.S. Census Question on Immigrants’ Year of Arrival.” Demography 41 (November): 721-738.

Robinson, John P., Paul DiMaggio, and Eszter Hargittai. 2003. “New Social Survey Perspectives on the Digital Divide.” IT \& Society 1 (Summer): 1-22.

Spooner, Tom and Lee Rainie. 2001. “Hispanics and the Internet.” Mimeo, Pew Internet \& American Life Project.

Stanley, Laura D. 2003. “Beyond Access: Psychosocial Barriers to Computer Literacy.” The Information Society 19: 407-416.

U.S. Census Bureau. 2004a. "Income, Poverty, and Health Insurance Coverage in the United States: 2003.” Current Population Reports P60-226. Washington, DC: U.S. Department of Commerce.

. 2004b. "Educational Attainment in the United States: 2003.” Current Population Reports P20-550. Washington, DC: U.S. Department of Commerce. 
U.S. Department of Commerce. 2002. A Nation Online: How Americans are Expanding their Use of the Internet. Washington, D.C.: U.S. Department of Commerce.

2004. A Nation Online: Entering the Broadband Age. Washington, D.C.: U.S. Department of Commerce.

Van Dijk, Jan and Kenneth Hacker. 2003. "The Digital Divide as a Complex and Dynamic Phenomenon.” The Information Society 19: 315-326.

Warschauer, Mark. 2003. Technology and Social Inclusion: Rethinking the Digital Divide. Cambridge, MA: MIT Press.

Zoghi, Cindy and Sabrina W. Pabilonia. 2007. "Which Workers Gain upon Adopting a Computer?” Canadian Journal of Economics 40: 423-444. 
Table 1: Sample Means

\begin{tabular}{|c|c|c|}
\hline & Natives & Immigrants \\
\hline Household owns computer & .57 & .47 \\
\hline Uses computer at home, conditional on ownership & .82 & .67 \\
\hline Uses Internet at home, conditional on ownership & .64 & .53 \\
\hline Uses computer at work, conditional on working & .57 & .36 \\
\hline Uses Internet anywhere & .47 & .32 \\
\hline Age & 44.6 & 42.2 \\
\hline Female & .52 & .50 \\
\hline $\begin{array}{l}\text { Education: } \\
\text { College graduate } \\
\text { Some college } \\
\text { High school graduate } \\
\text { Less than high school graduate }\end{array}$ & $\begin{array}{l}.24 \\
.29 \\
.33 \\
.13\end{array}$ & $\begin{array}{l}.25 \\
.17 \\
.24 \\
.34\end{array}$ \\
\hline $\begin{array}{l}\text { Race and ethnicity: } \\
\text { White, non-Hispanic } \\
\text { Black } \\
\text { Native American } \\
\text { Asian } \\
\text { Other race } \\
\text { Hispanic }\end{array}$ & $\begin{array}{r}.80 \\
.12 \\
.01 \\
.01 \\
.003 \\
.06\end{array}$ & $\begin{array}{r}.23 \\
.07 \\
.003 \\
.23 \\
.001 \\
.46\end{array}$ \\
\hline $\begin{array}{l}\text { Marital status: } \\
\text { Married } \\
\text { Divorced } \\
\text { Never-married }\end{array}$ & $\begin{array}{l}.56 \\
.20 \\
.24\end{array}$ & $\begin{array}{l}.60 \\
.18 \\
.22\end{array}$ \\
\hline $\begin{array}{l}\text { English ability (predicted): } \\
\text { Speaks only English at home } \\
\text { Speaks English very well } \\
\text { Speaks English well } \\
\text { Speaks English not well } \\
\text { Speaks English not at all }\end{array}$ & $\begin{array}{r}.98 \\
.02 \\
.002 \\
.000 \\
.000\end{array}$ & $\begin{array}{l}.15 \\
.33 \\
.11 \\
.38 \\
.03\end{array}$ \\
\hline Sample size & 357,793 & 44,985 \\
\hline
\end{tabular}

Note: Shown are weighted means based on the Current Population Survey computer use supplements in 1997, 1998, 200, 2001 and 2003. The sample sizes are smaller for the conditional IT variables. English ability is predicted using age, sex, education, race/ethnicity, marital status, years since migration, U.S. citizenship, place of birth, and state of residence based on the 2000 Census. 
Table 2: Relationship between immigrant status and measures of IT access and use

\begin{tabular}{|c|c|c|c|c|c|}
\hline & $\begin{array}{c}\text { Household owns } \\
\text { computer }\end{array}$ & $\begin{array}{c}\text { Uses computer } \\
\text { at home }\end{array}$ & $\begin{array}{c}\text { Uses Internet } \\
\text { at home }\end{array}$ & $\begin{array}{c}\text { Uses computer } \\
\text { at work }\end{array}$ & $\begin{array}{c}\text { Uses Internet } \\
\text { anywhere }\end{array}$ \\
\hline \multicolumn{6}{|c|}{ A. Effect of immigrant status, relative to natives } \\
\hline Immigrant & $\begin{array}{l}0.869 * * \\
(0.015)\end{array}$ & $\begin{array}{l}0.555^{* *} \\
(0.016)\end{array}$ & $\begin{array}{l}0.698 * * \\
(0.015)\end{array}$ & $\begin{array}{l}0.549 * * \\
(0.015)\end{array}$ & $\begin{array}{l}0.624 * * \\
(0.012)\end{array}$ \\
\hline Log likelihood & $-202,041$ & $-63,774$ & $-127,473$ & $-92,739$ & $-186,583$ \\
\hline \multicolumn{6}{|c|}{ B. Effect of immigrant status, relative to natives, by survey year } \\
\hline Immigrant * 1997 & $\begin{array}{l}0.775 * * \\
(0.029)\end{array}$ & $\begin{array}{l}0.639 * * \\
(0.039)\end{array}$ & $\begin{array}{l}0.866^{* *} \\
(0.048)\end{array}$ & $\begin{array}{l}0.414^{* *} \\
(0.021)\end{array}$ & $\begin{array}{l}0.704^{* *} \\
(0.031)\end{array}$ \\
\hline Immigrant * 1998 & $\begin{array}{l}0.813^{* *} \\
(0.030)\end{array}$ & & $\begin{array}{c}0.911 \\
(0.045)\end{array}$ & & $\begin{array}{l}0.633^{* *} \\
(0.026)\end{array}$ \\
\hline Immigrant $* 2000$ & $\begin{array}{l}0.677^{* *} \\
(0.025)\end{array}$ & & $\begin{array}{l}0.726 * * \\
(0.034)\end{array}$ & & $\begin{array}{l}0.522 * * \\
(0.020)\end{array}$ \\
\hline Immigrant $* 2001$ & $\begin{array}{l}0.754^{* *} \\
(0.027)\end{array}$ & $\begin{array}{l}0.517 * * \\
(0.027)\end{array}$ & $\begin{array}{l}0.654^{* *} \\
(0.029)\end{array}$ & $\begin{array}{l}0.389 * * \\
(0.019)\end{array}$ & $\begin{array}{l}0.486^{* *} \\
(0.018)\end{array}$ \\
\hline Immigrant * 2003 & $\begin{array}{c}0.647 \\
(0.024)\end{array}$ & $\begin{array}{l}0.512 * * \\
(0.028)\end{array}$ & $\begin{array}{l}0.637^{* *} \\
(0.029)\end{array}$ & $\begin{array}{l}0.394^{* *} \\
(0.020)\end{array}$ & $\begin{array}{l}0.460 * * \\
(0.017)\end{array}$ \\
\hline $\begin{array}{l}\text { Years of U.S reside } \\
\text { among immigrants }\end{array}$ & $\begin{array}{l}\text { ce } 1.010 * * \\
(0.001)\end{array}$ & $\begin{array}{l}1.001^{* *} \\
(0.002)\end{array}$ & $\begin{array}{c}0.998 \\
(0.001)\end{array}$ & $\begin{array}{l}1.019 * * \\
(0.002)\end{array}$ & $\begin{array}{l}1.009 * * \\
(0.001)\end{array}$ \\
\hline Log likelihood & $-201,941$ & $-63,763$ & $-127,428$ & $-92,658$ & $-186,472$ \\
\hline Sample size & 402,778 & 147,611 & 229,038 & 166,686 & 402,778 \\
\hline
\end{tabular}

$* \mathrm{p}<0.05 ; * * \mathrm{p}<0.01$

Note: Shown are estimated odds ratios (standard errors) for an indicator variable that equals 1 for immigrants and 0 for natives in logistic regressions with the indicated dependent variable. Each coefficient is from a separate regression. The samples for columns 2 and 3 are conditional on living in a household that owns a computer, and the sample in column 4 is conditional on working. All regressions include controls for the other individual characteristics listed in Table 1, family income (13 categories) interacted with survey year fixed effects, state of residence fixed effects, and survey year fixed effects. 
Table 3: Relationship between immigrant status, Spanish-only households and measures of IT access and use

\begin{tabular}{|c|c|c|c|c|c|}
\hline & $\begin{array}{c}\text { Household owns } \\
\text { computer }\end{array}$ & $\begin{array}{c}\text { Uses computer } \\
\text { at home }\end{array}$ & $\begin{array}{c}\text { Uses Internet } \\
\text { at home }\end{array}$ & $\begin{array}{c}\text { Uses computer } \\
\text { at work }\end{array}$ & $\begin{array}{c}\text { Uses Internet } \\
\text { anywhere }\end{array}$ \\
\hline Immigrant & $\begin{array}{l}0.855^{* *} \\
(0.022)\end{array}$ & $\begin{array}{l}0.572 * * \\
(0.026)\end{array}$ & $\begin{array}{l}0.775^{* *} \\
(0.026)\end{array}$ & $\begin{array}{l}0.454^{* *} \\
(0.019)\end{array}$ & $\begin{array}{l}0.629 * * \\
(0.018)\end{array}$ \\
\hline $\begin{array}{l}\text { Immigrant*Spanish- } \\
\text { speaking household }\end{array}$ & $\begin{array}{l}0.423^{* *} \\
(0.018)\end{array}$ & $\begin{array}{l}0.670 * * \\
(0.056)\end{array}$ & $\begin{array}{l}0.517 * * \\
(0.018)\end{array}$ & $\begin{array}{l}0.380 * * \\
(0.032)\end{array}$ & $\begin{array}{l}0.347 * * \\
(0.019)\end{array}$ \\
\hline $\begin{array}{l}\text { Native*Spanish- } \\
\text { speaking household }\end{array}$ & $\begin{array}{l}0.851^{* *} \\
(0.047)\end{array}$ & $\begin{array}{c}0.872 \\
(0.101)\end{array}$ & $\begin{array}{c}0.892 \\
(0.065)\end{array}$ & $\begin{array}{l}0.073^{* *} \\
(0.058)\end{array}$ & $\begin{array}{l}0.780^{* *} \\
(0.046)\end{array}$ \\
\hline $\begin{array}{l}\text { Years of U.S residenc } \\
\text { among immigrants }\end{array}$ & $\begin{array}{l}\text { ce } 1.001^{* *} \\
(0.001)\end{array}$ & $\begin{array}{l}1.000 * * \\
(0.002)\end{array}$ & $\begin{array}{l}0.996 * * \\
(0.001)\end{array}$ & $\begin{array}{l}1.016^{* *} \\
(0.002)\end{array}$ & $\begin{array}{l}1.005^{* *} \\
(0.001)\end{array}$ \\
\hline Log likelihood & $-201,632$ & $-63,757$ & $-127,415$ & $-92,537$ & $-186,241$ \\
\hline
\end{tabular}

$* \mathrm{p}<0.05 ; * * \mathrm{p}<0.01$

Note: Shown are estimated odds ratios (standard errors) for an indicator variable that equals 1 for immigrants and 0 for natives in logistic regressions with the indicated dependent variable. Each coefficient is from a separate regression. The samples for columns 2 and 3 are conditional on living in a household that owns a computer, and the sample in column 4 is conditional on working. All regressions include controls for the other individual characteristics listed in Table 1, family income (13 categories) interacted with survey year fixed effects, state of residence fixed effects, and survey year fixed effects. 
Table 4: Relationship between predicted English ability, immigrant status, and measures of IT access and use

\begin{tabular}{|c|c|c|c|c|c|}
\hline & $\begin{array}{c}\text { Household owns } \\
\text { computer }\end{array}$ & $\begin{array}{c}\text { Uses computer } \\
\text { at home }\end{array}$ & $\begin{array}{c}\text { Uses Internet } \\
\text { at home }\end{array}$ & $\begin{array}{c}\text { Uses computer } \\
\text { at work }\end{array}$ & $\begin{array}{c}\text { Uses Internet } \\
\text { anywhere }\end{array}$ \\
\hline \multicolumn{2}{|c|}{$\begin{array}{l}\text { Speaks English very well0.967 } \\
\qquad(0.030)\end{array}$} & $\begin{array}{l}0.669 * * \\
(0.038)\end{array}$ & $\begin{array}{l}0.749 * * \\
(0.031)\end{array}$ & $\begin{array}{l}0.719 * * \\
(0.035)\end{array}$ & $\begin{array}{l}0.765^{* *} \\
(0.026)\end{array}$ \\
\hline Speaks English well & $\begin{array}{c}1.014 \\
(0.051)\end{array}$ & $\begin{array}{l}0.483^{* *} \\
(0.042)\end{array}$ & $\begin{array}{l}0.621 * * \\
(0.040)\end{array}$ & $\begin{array}{l}0.626 * * \\
(0.048)\end{array}$ & $\begin{array}{l}0.666 * * \\
(0.036)\end{array}$ \\
\hline \multicolumn{2}{|c|}{$\begin{array}{l}\text { Speaks English not well0.751** } \\
\qquad(0.036)\end{array}$} & $\begin{array}{l}0.381^{* *} \\
(0.033)\end{array}$ & $\begin{array}{l}0.426^{* *} \\
(0.028)\end{array}$ & $\begin{array}{l}0.403^{* *} \\
(0.031)\end{array}$ & $\begin{array}{l}0.417^{* *} \\
(0.022)\end{array}$ \\
\hline Speaks no English & $\begin{array}{l}0.063 * * \\
(0.073)\end{array}$ & $\begin{array}{l}0.354^{* *} \\
(0.091)\end{array}$ & $\begin{array}{l}0.380 * * \\
(0.096)\end{array}$ & $\begin{array}{c}0.557^{*} \\
(0.142)\end{array}$ & $\begin{array}{l}0.320 * * \\
(0.056)\end{array}$ \\
\hline Immigrant & $\begin{array}{l}0.846 * * \\
(0.033)\end{array}$ & $\begin{array}{c}0.955 \\
(0.066)\end{array}$ & $\begin{array}{c}1.132 * \\
(0.057)\end{array}$ & $\begin{array}{l}0.655^{* *} \\
(0.039)\end{array}$ & $\begin{array}{l}0.872 * * \\
(0.037)\end{array}$ \\
\hline $\begin{array}{l}\text { Years of U.S residenc } \\
\text { among immigrants }\end{array}$ & $\begin{array}{l}\text { ce } 1.007 * * \\
(0.001)\end{array}$ & $\begin{array}{l}0.992 * * \\
(0.002)\end{array}$ & $\begin{array}{l}0.990 * * \\
(0.001)\end{array}$ & $\begin{array}{l}1.011^{* *} \\
(0.002)\end{array}$ & $\begin{array}{c}1.000 \\
(0.001)\end{array}$ \\
\hline Log likelihood & $-201,916$ & $-63,677$ & $-127,342$ & $-92,549$ & $-186,331$ \\
\hline
\end{tabular}

$* \mathrm{p}<0.05 ; * * \mathrm{p}<0.01$

Note: English ability is predicted based on the data from the 2000 Census (see text for details), with speaking only English at home as the omitted group. Shown are estimated odds ratios (standard errors) for an indicator variable that equals 1 for immigrants and 0 for natives in logistic regressions with the indicated dependent variable. Each coefficient is from a separate regression. The samples for columns 2 and 3 are conditional on living in a household that owns a computer, and the sample in column 4 is conditional on working. All regressions include controls for the other individual characteristics listed in Table 1, family income (13 categories) interacted with survey year fixed effects, state of residence fixed effects, and survey year fixed effects. 


\section{Appendix Table 1: Sample Means for Variables and Sample Sizes by Survey Year in CPS}

\begin{tabular}{|c|c|c|}
\hline & Natives & Immigrants \\
\hline \multicolumn{3}{|l|}{ Family income: } \\
\hline Less than $\$ 5000$ & .03 & .04 \\
\hline$\$ 5000$ to $\$ 7499$ & .03 & .03 \\
\hline$\$ 7500$ to $\$ 9999$ & .03 & .04 \\
\hline$\$ 10,000$ to $\$ 12,499$ & .03 & .05 \\
\hline$\$ 12,500$ to $\$ 14,999$ & .03 & .05 \\
\hline$\$ 15,000$ to $\$ 19,999$ & .05 & .07 \\
\hline$\$ 20,000$ to $\$ 24,999$ & .07 & .09 \\
\hline$\$ 25,000$ to $\$ 29,999$ & .07 & .08 \\
\hline$\$ 30,000$ to $\$ 34,999$ & .07 & .08 \\
\hline$\$ 35,000$ to $\$ 39,999$ & .06 & .06 \\
\hline$\$ 40,000$ to $\$ 49,999$ & .10 & .08 \\
\hline$\$ 50,000$ to $\$ 59,999$ & .10 & .08 \\
\hline$\$ 60,000$ to $\$ 74,999$ & .10 & .07 \\
\hline$\$ 75,000$ or higher & .23 & .17 \\
\hline Years since migration & - & 16.9 \\
\hline U.S. citizen & 1.00 & .39 \\
\hline Fraction speak English in country of birth & .87 & .08 \\
\hline \multicolumn{3}{|l|}{ Sample size by survey: } \\
\hline October 1997 & 70,704 & 8,026 \\
\hline December 1998 & 69,001 & 8,063 \\
\hline August 2000 & 65,824 & 8,591 \\
\hline September 2001 & 77,725 & 9,471 \\
\hline October 2003 & 74,411 & 9,377 \\
\hline
\end{tabular}

Note: Shown are weighted means based on the Current Population Survey computer use supplements in 1997, 1998, 200, 2001 and 2003. 


\section{Appendix Table 2: Sample Means for Census Data}

\begin{tabular}{lcc}
\hline & Natives & Immigrants \\
\hline Age & 44.8 & 42.0 \\
Female & .52 & .51 \\
Education: & & \\
$\quad$ College graduate & .22 & .21 \\
$\quad$ Some college & .30 & .19 \\
$\quad$ High school graduate & .31 & .20 \\
$\quad$ Less than high school graduate & .17 & .40
\end{tabular}

Race and ethnicity:

White, non-Hispanic

.80

.21

Black

$.11 \quad .06$

Native American

.01

.00

Asian

.01

.23

Other race

.03

Hispanic

.01

.47

Marital status:

Married

.06

Divorced

$.72 \quad .72$

Never-married

.11

.11

$.17 \quad .18$

English ability:

Speaks only English at home $\quad .92 \quad .16$

Speaks English very well

$.06 \quad .31$

Speaks English well

$.01 \quad .22$

Speaks English not well

$.01 \quad .21$

Speaks English not at all

.00

.11

Family income:

Less than $\$ 5000$

$\$ 5000$ to $\$ 7499$

.01

.02

$\$ 7500$ to $\$ 9999$

.01

.01

$\$ 10,000$ to $\$ 12,499$

.01

.02

$\$ 12,500$ to $\$ 14,999$

.02

.03

$\$ 15,000$ to $\$ 19,999$

.02

.03

$\$ 20,000$ to $\$ 24,999$

.04

.06

$\$ 25,000$ to $\$ 29,999$

.05

.07

$\$ 30,000$ to $\$ 34,999$

.05

.07

$\$ 35,000$ to $\$ 39,999$

$.06 \quad .07$

$\$ 40,000$ to $\$ 49,999$

$.06 \quad .06$

$\$ 50,000$ to $\$ 59,999$

$.11 \quad .11$

$\$ 60,000$ to $\$ 74,999$

.11

.09

$\$ 75,000$ or higher

.13

.11

Years since migration

- $\quad 17.5$


U.S. citizen

Fraction speak English in country of birth

Sample size
1.00

.87

$1,169,422$
.43

.08

935,936

Note: Shown are weighted means based on the 2000 Census Public Use Microdata 5\% Sample. 


\section{Appendix Table 3: Ordered Logit Results Used to Predict English Ability}

\begin{tabular}{ll}
\hline & English ability \\
\hline Immigrant & $-1.963^{* *}$ \\
& $(0.018)$ \\
Years of U.S. residence among immigrants & $0.036^{* *}$ \\
& $(0.000)$ \\
U.S. citizen & $0.275^{* *}$ \\
& $(0.008)$ \\
Fraction speak English in country of birth & $2.518^{* *}$ \\
& $(0.017)$ \\
Fraction speak English * Years of U.S. residence & $0.027^{* *}$ \\
& $(0.001)$ \\
Log likelihood & $-844,538.32$ \\
\hline
\end{tabular}

Note: Shown are estimated coefficients (standard errors) from an ordered logit regression. The dependent variable is English ability, which ranges from 0 to 4, with higher scores indicating greater fluency. The regression include controls for the other individual characteristics listed in Appendix Table 2 and state of residence fixed effects. 


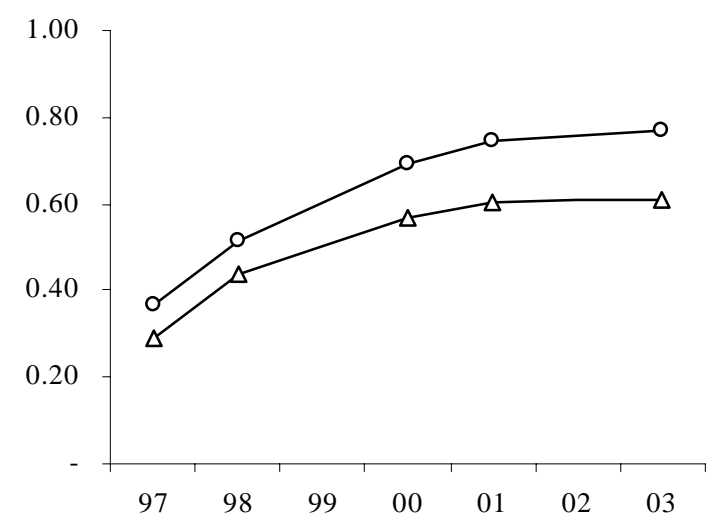

(a) PC ownership at home

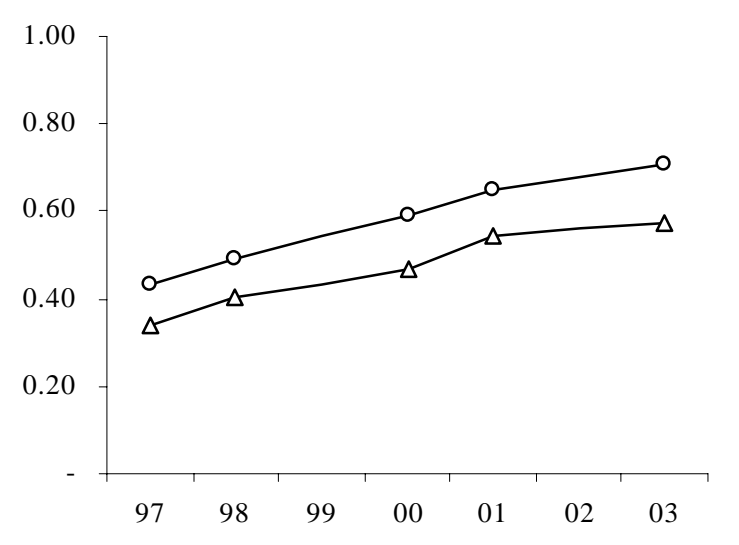

(c) Internet use at home given PC ownership

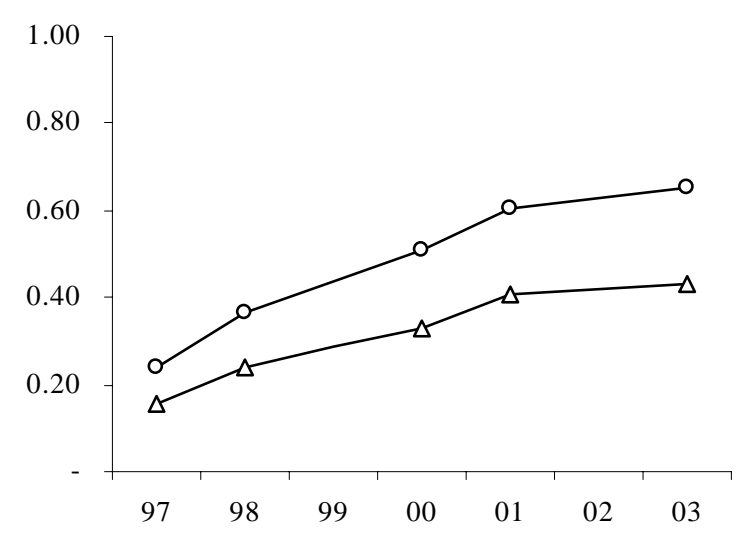

(e) Internet use from anywhere

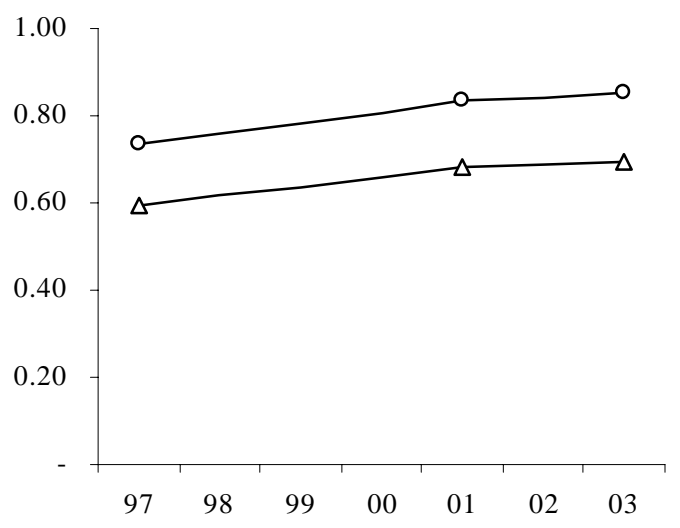

(b) PC use at home given ownership

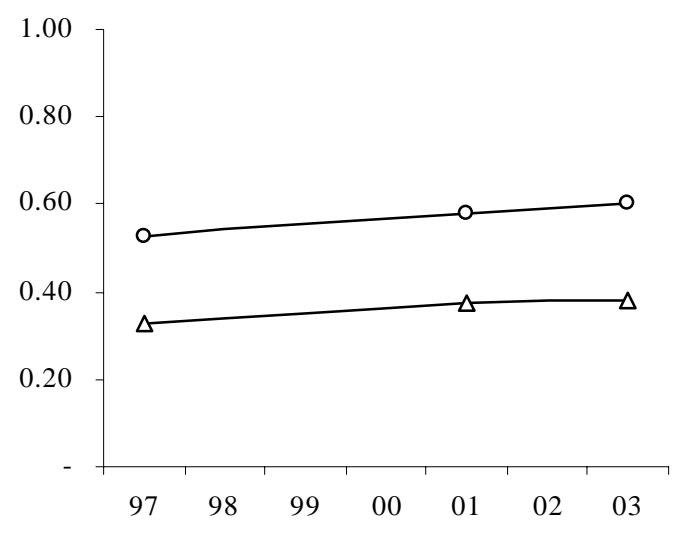

(d) Computer use at work

Figure 1: Immigrant-Native Gap in IT Access and Use (1997 to 2003) 